\title{
Investigation of genetic variation in Jatropha curcas by Ecotilling and ISSR
}

\author{
Fatemeh Maghuly ${ }^{1 *}$, Joanna Jankowicz-Cieslak ${ }^{2}$, Alberto Calari ${ }^{1}$, Rose Ramkat ${ }^{1}$, Bradley Till ${ }^{2}$, Margit Laimer ${ }^{1}$ \\ From IUFRO Tree Biotechnology Conference 2011: From Genomes to Integration and Delivery \\ Arraial d'Ajuda, Bahia, Brazil. 26 June - 2 July 2011
}

\section{Background}

The ability of species to adapt to different environments resides in their genetic diversity. This diversity, most commonly manifested as Single Nucleotide Polymorphisms (SNPs), can provide clues to the adaptive processes and population histories that have played a role in the species' evolution. A number of different techniques for identifying SNPs have been developed, all having their limitations.

Reverse genetics approaches rely on the detection of sequence alterations in target genes to identify allelic variations in natural or mutant populations. Ecotilling, a variant of TILLING (Targeting Induced Local Lesions IN Genomes) technique, allows high-throughput analyses of natural genetic diversity in plants [1], particularly in species with limited genetic diversity.

Jatropha curcas L. is a perennial, monoecious shrub of the Euphorbiaceae family, native to America but distributed widely in the tropical and subtropical areas [2]. Wild or semi-cultivated types of J. curcas can grow well under unfavourable climatic and soil conditions [3]. J. curcas has attracted a great deal of attention worldwide, regarding its potential as a new energy plant. The seeds of $J$. curcas contain $30-45 \%$ oil [4] with a high percentage of monounsaturated oleic and polyunsaturated linoleic acid [5]. For genomic analyses, J. curcas is an interesting model species, since it has a relatively small genome $(2 \mathrm{C}$ DNA content of $0.850 \pm 0.006 \mathrm{pg}$ or $\mathrm{C}$ DNA content of $0.416 \times 109 \mathrm{bp})$ [6].

However, to achieve specific breeding goals in Jatropha for wider ecological adaptation, disease resistance and novel seed quality, the use of germplasm from different group and regions is necessary. Understanding

\footnotetext{
* Correspondence: fatemeh.maghuly@boku.ac.at

'Plant Biotechnology Unit (PBU), Dept. Biotechnology, University of Natural Resources and Life Sciences, Muthgasse 18, 1190 Vienna, Austria Full list of author information is available at the end of the article
}

the population structure of the alternative bioenergy plant Jatropha curcas is challenging due to limited genetic variability and information on phylogenetic relationships between accessions and related species. The development of cultivars of Jatropha curcas by conventional breeding will profit largely from biotechnological support (pathogen-free accessions with specific traits, non-toxic, high yielding varieties).

The knowledge about J. curcas remains limited and little genomic research has been done so far [7]. In fact, the genetic map of $J$. curcas is not well-developed and only few molecular markers exist that could be used to clearly distinguish world wide accessions. Therefore, a resource database of SNPs in J. curcas would provide researchers with a tool for answering questions concerning population structure or adaptation and allow comparison of this species with related species.

\section{Methods}

The identification of novel SNPs that account for natural variation was used to study genetic diversity and the relationships between and within Jatropha species. ISSRs (Inter Simple Sequence Repeats) also were considered as a tool in selecting germplasm for breeding purposes.

An in vitro germplasm collection of 1300 accessions from 12 countries was established. This collection will serve different purposes: a) conserve valuable genetic resources, b) survey genetic variation, and c) serve as starting material for genetic improvement with different breeding goals.

Ecotilling was applied to 12 different genes of interest related to stress tolerance, toxin and oil metabolism. 50 ISSR primers were used to assess the genetic diversity of Jatropha curcas and related species. Four different pooling strategies were used to identify homozygous and heterozygous SNP variations. In fact, variation was analyzed both within a single tree (heterozygous) as well as 
between individual trees and a reference samples. Due to the reported low variations between Jatropha accessions $[8,9]$ and large size of our collection, the $8 \times 8$ pooling strategy was chosen to estimate the level of variations among 12 selected genes.

\section{Results and conclusions}

To elucidate genetic relationship among Jatropha accessions from different regions and related species, a dendrogram was produced using NJ analysis of NeiÂ's genetic distance for 5 ISSR markers. The dendrogram is divided into two groups, one containing all Jatropha accessions and the other containing the related species. The main Jatropha curcas cluster is divided into two subclusters, one containing samples from Kenya and the other containing the remaining Jatropha accessions. The data showed clear variations not only among individuals but also between different regions.

Ecotilling was found to be more efficient for largescale studies of genetic variation in Jatropha, compared to RAPD, SSR and AFLP. Ecotilling is a low cost, highthroughput reverse genetic method for haplotyping and SNPs discovery.The level of differentiation observed was based on the geographic distribution pattern, i.e. it was higher in the centre of origin. ISSR analysis yielded highly reproducible patterns with $5 / 50$ primers.

\section{Acknowledgements}

Financial support of FFG project 820132 and Bioplant R \& D is acknowledged.

\section{Author details}

'Plant Biotechnology Unit (PBU), Dept. Biotechnology, University of Natural Resources and Life Sciences, Muthgasse 18, 1190 Vienna, Austria. ${ }^{2}$ Plant Breeding Unit, FAO/IAEA Agricultural and Biotechnology Laboratory, International Atomic Energy Agency, P.O. Box 100, Vienna International Centre, 1400 Vienna, Austria.

Published: 13 September 2011

\section{References}

1. Comai L, Young K, Till B, Reynolds SH, Greene EA, Codomo CA, Enns LC, Johnson JE, Burtner C, Odden AR, Henikoff S: Efficient discovery of DNA polymorphisms in natural populations by Ecotilling. Plant J 2004, 37:778-786.

2. Cano-Asseleih LM, Plumbly RA, Hylands PJ: Purification and partial characterization of the hemagglutination from seeds of Jatropha curcasL. Jour Food Biochem 1989, 13:1-20.

3. Katwal RPS, Soni PL: Biofuels: an opportunity for socioeconomic development and cleaner environment. Indian Forester 2003, 129:939-949.

4. Openshaw K: A review of Jatropha curcas: an oil plant of unfulfilled promise. Biomass Bioenerg 2000, 19:1-15.

5. Akintayo ET: Characteristics and composition of Parkia biglobbossa and Jatropha curcasL. oils and cakes. Bioresour Technol 2004, 92:307-310.

6. Carvalho CR, Clarindo WR, Praca MM, Arauja FS, Carels N: Genome size, base composition and karyotype of JatrophacurcasL., an important biofuel plant. Plant Science 2008, 174:613-617.

7. Wen M, Wang H, Xia, Zou M, Lu C, Wang W: Developmenrt of EST-SSR and genomic-SSR markers to assess genetic diversity in Jatropha curcas L. BMC. Res Notes 2010, 3:42.
8. Achten MJW, Nielsen LR, Aerts R, Lengkeek AG, Kjaer ED, Trabucco A, Hansen JK, Maes WH, Graudal L, Akinnifesi FK, Muys B: Towards domestication of Jatropha curcas: a review. Biofuels 2010, 1:91-107.

9. Vollmann J, Laimer M: Novel and traditional oil crops and their biorefinery potential. In Bioprocessing Technologies in Integrated Biorefinery for Production of Biofuels, Biochemicals, and Biopolymers from Biomass. John Wiley \& Sons, Inc. (USA); Yang S-T, El Enshasy HA, Thongchul N, Martin Lo Y 2010:

\section{doi:10.1186/1753-6561-5-S7-050}

Cite this article as: Maghuly et al:: Investigation of genetic variation in Jatropha curcas by Ecotilling and ISSR. BMC Proceedings 2011 5(Suppl 7): O50.

\section{Submit your next manuscript to BioMed Central and take full advantage of:}

- Convenient online submission

- Thorough peer review

- No space constraints or color figure charges

- Immediate publication on acceptance

- Inclusion in PubMed, CAS, Scopus and Google Scholar

- Research which is freely available for redistribution 